\title{
Medical Equipment Manufacturing Enterprise Informatization Management System Review
}

\author{
Yingge Lou \\ Electronic Information Engineering Institute \\ Tongji University, \\ Shanghai, China, +86 13916669942 \\ 87_louyingge@tongji.edu.cn
}

\author{
Shuo Yang \\ Electronic Information Engineering Institute \\ Tongji University, \\ Shanghai, China, +86 15921534380 \\ 314shouyang@tongji.edu.cn
}

\begin{abstract}
This paper is based on the analysis of the unified standards, the main construction contents, the model and steps that an informatization system should take during its construction and implementation, which medical equipment manufacturing enterprises face in the process of informatization. In this paper, we give a framework model of medical equipment manufacturing enterprise informatization management system, then design and implement the platform system. This platform system includes normative documents management, informatization carried standard management, the main contents of informatization construction management, typical successful cases management, recommended implementation model and steps of informatization construction and some other functional modules.
\end{abstract}

KeyWords-Standards; Medical Equipment Manufacturing; Enterprise Informatization

\section{INTRODUCTION}

In the process of Chinese medical equipment manufacturing enterprise informatization construction and implementation, there are two outstanding problems which trouble the enterprises: one is the informatization standards that enterprises should follow, and the other is the contents and implementation model of the informatization construction of enterprises. Therefore, it has become a problem which needs urgent solution that we should design an informatization management platform which can offer help to medical equipment manufacturing enterprises in aspect as informatization standards, informatization construction contents, implementation model, etc, and guide the enterprises to implement informatization construction effectively. This paper will discuss these issues.

\section{PRoblems that Chinese Medical EquiPMENT MANUFACTURING ENTERPRISES FACE}

Enterprise informatization is a strategic issue for the survival and development of enterprises, and the informatization of Chinese Medical Equipment Manufacturing Enterprises is getting deep and deep ceaselessly, however, there are two outstanding problems that trouble the enterprises:

\section{A. Relevant Standards that Medical Equipment} Manufacturing Enterprise Informatization should Follow

Enterprise informatization should follow the unified informatization standards. And without them, it will be bound to cause isomerism in data structure of system, form the information islands, and create difficulties to system integration in the future.

Clear and unified informatization standards can help enterprise information system avoid isomerism in the source of data structure, lay a solid foundation for the expansion and integration of enterprise information system in the future, and protect the existing input furthest in budget, time and other aspects.

\section{B. the Main Contents and Implementation Model of \\ Enterprise Informatization Construction}

Enterprise informatization involves to the enterprise daily affairs management informatization, and the informatization of enterprise's product design, production, sales, service, decision-making, etc. It is very important for enterprises to clear the essence of enterprise informatization construction and determine a feasible informatization construction and implementation model according to their actual requirements in their work of informatization construction and implementation.

\section{FunCTIONAL REQUIREMENTS OF MEDICAL EQUIPMENT MANUFACTURING ENTERPRISE INFORMATIZATION MANAGEMENT SYSTEMP}

The essence of enterprise informatization is to program and make overall arrangements to all the resources of the enterprise, in order to achieve the optimal configuration of the enterprise resources, shorten the enterprise's operation procedure, and save the cost of the enterprise. According to the actual requirements of Chinese medical equipment manufacturing enterprise informatization, the informatization management system shall include the following contents:

- Manage the existing normative documents of medical enterprises at home and abroad, including international standards, national standards, industry standards, enterprise standards, etc.

- Establish medical equipment manufacturing enterprise informatization carried standard, and carry out the 
management of it effectively, to provide standards and specifications for the enterprises to promote their informatization construction.

- Make clear the contents of medical equipment manufacturing enterprise informatization construction, and guide the informatization construction and implementation of enterprises.

- Make clear the implementation model and steps of medical equipment manufacturing enterprise informatization construction, and guide enterprises to carry on their informatization construction orderly.

- Manage the successful typical cases of enterprise informatization construction at home and abroad, in order to offer references for enterprises in their process of informatization.

\section{DESIGN AND IMPLEMENTATION OF SYSTEM}

\section{A. System Architecture}

The holistic architecture of medical equipment manufacturing enterprise informatization management system is shown in Figure 1. This architecture is based on the enterprise public network platform. Combining with information standards and system safety, it builds the enterprise application system platform including medical enterprise document standards and carried standards, construction contents, implementation model, typical cases management and other main functional modules.

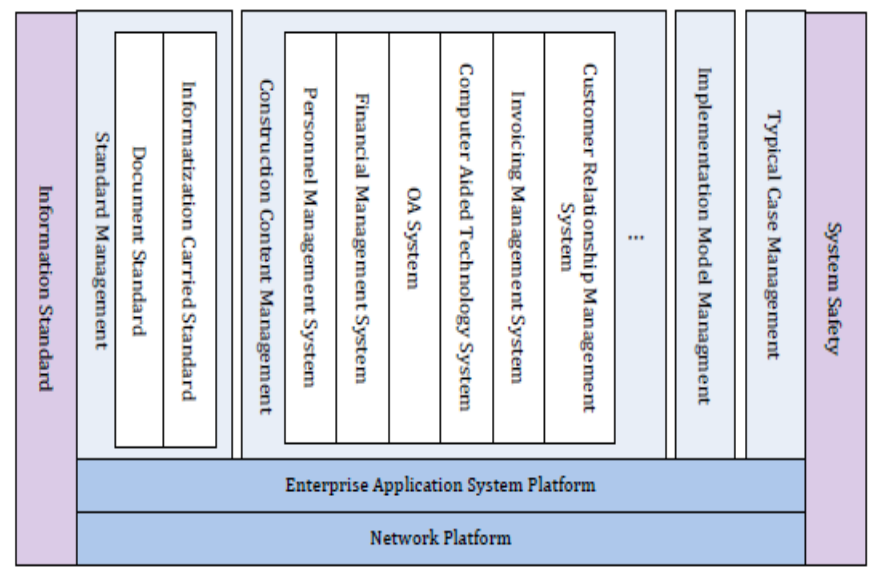

Figure 1. Architecture of Medical Equipment Manufacturing Enterprise Informatization Management System

\section{B. Database Design}

Database design is an important link of medical equipment industry informatization system development. The main data table with its function which the database of this system involves is shown in Table I.
TABLE I. SYSTEM DATABASE TABLE

\begin{tabular}{|c|c|}
\hline Database Table Name & Corresponding Function \\
\hline Medical equipment standards table & $\begin{array}{l}\text { Corresponding medical equipment } \\
\text { standards including international } \\
\text { standards, national standards, industry } \\
\text { standards, enterprise standards, etc. }\end{array}$ \\
\hline $\begin{array}{l}\text { Medical equipment enterpri } \\
\text { documents management table }\end{array}$ & $\begin{array}{l}\text { Use to manage the guidance documents } \\
\text { and corresponding files in the process } \\
\text { of medical equipment manufacturing } \\
\text { enterprise informatization. }\end{array}$ \\
\hline $\begin{array}{l}\text { Publishing department table } \\
\text { medical equipment standards }\end{array}$ & $\begin{array}{l}\text { Match the corresponding publishing } \\
\text { department of medical equipment } \\
\text { standards, use for the multi-condition } \\
\text { query of medical equipment standards. }\end{array}$ \\
\hline $\begin{array}{l}\text { Competent department table } \\
\text { medical equipment standards }\end{array}$ & $\begin{array}{l}\text { Match the competent department of } \\
\text { medical equipment standards, use for } \\
\text { the multi-condition query of medical } \\
\text { equipment standards. }\end{array}$ \\
\hline $\begin{array}{l}\text { Centralized unit table of medi } \\
\text { equipment standards }\end{array}$ & $\begin{array}{l}\text { Match the centralized unit of medical } \\
\text { equipment standards, use for the multi- } \\
\text { condition query of medical equipment } \\
\text { standards. }\end{array}$ \\
\hline $\begin{array}{l}\text { Year statistics table of medi } \\
\text { equipment standards }\end{array}$ & $\begin{array}{l}\text { Use to statistic data in each year of } \\
\text { medical equipment standards, make it } \\
\text { more convenient for users to filter data } \\
\text { in year. }\end{array}$ \\
\hline Links management table & $\begin{array}{l}\text { Manage the corresponding links in } \\
\text { system }\end{array}$ \\
\hline User permission management table & $\begin{array}{l}\text { Use to implement user permission } \\
\text { management, ensure the security of } \\
\text { system. }\end{array}$ \\
\hline
\end{tabular}

\section{System Construction Content Design}

1) Standards Management: Medical equipment manufacturing enterprise informatization standards can be divided into normative document standards and medical equipment informatization carried standards.

a) Normative Document Standards: Include international standards, national standards, industry standards and enterprise standards. These document standards set the related terminology of medical equipments, general model and framework, classification standard, coding mode and data collecting standard, etc. Against these normative documents, we need to set up a complete query and management module, include these document standards into system no matter in what form they are, and then provide users with multicondition and multi-branch query function, in order to provide business norms that should be followed by enterprises in their process of business development.

b) Carried Standaards: Medical equipment informatization carried standard is the foundation of data exchange and interoperation between different informatization management systems. It guides enterprises to carry out standardization and orderly informatization construction, and makes enterprises have standard to depend on in their process of informatization construction, which can avoid isomerism effectively.

Carried standard is closely related with information system. It requires uniform standard, uniform code and uniform interface.

Among them, uniform stadard is used mainly for the regulation of the functions list, technical requirements and 
information security \& privacy protection which a medical information system should have; Uniform Code requires the data dictionary of information system to adopt the corresponding related standards. It should be strictly in accordance with the coding principle of standards when we use standards that allow users to expand, and we have to use standard code immediately after it is issued; And Uniform interface requires information system of each medical enterprise and each subsystem of a single information system to adopt uniform external interface, and regulate the function of each interface.

The examples of medical equipment informatization data standard are shown in Table II. The informatization standard in it is essential when enterprises carry out their informatization construction.

The interface of medical equipment standards management of system is shown in Figure 2.

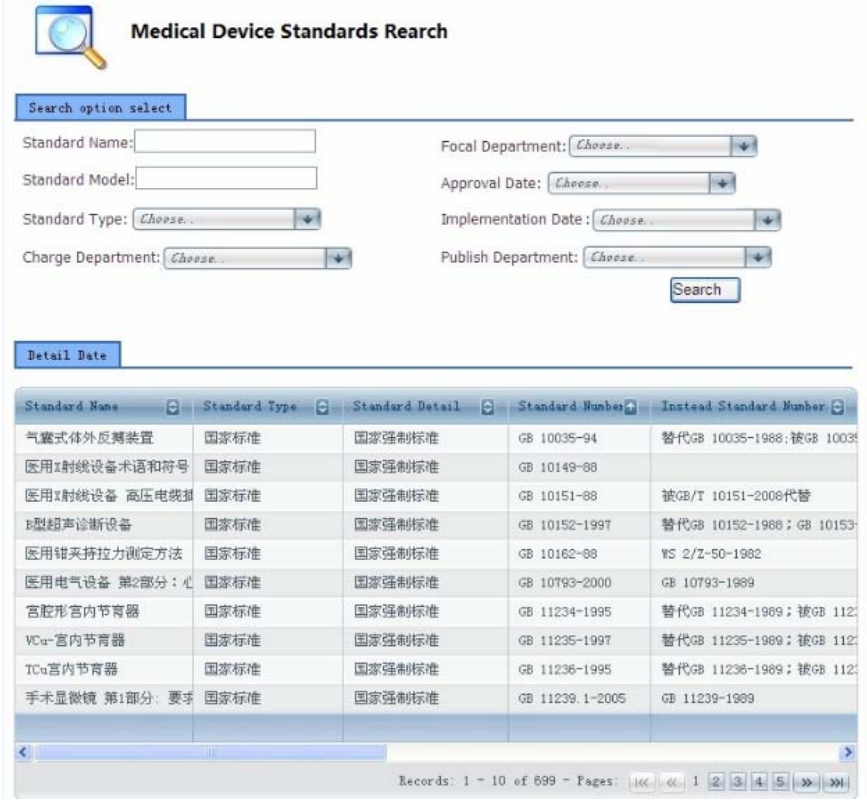

Figure 2. Interface of Medical Equipment Standard Management

2) Construction Contents and Implementation Model Management: This module mainly points out the essential contents of enterprise informatization construction, and offers corresponding guidance and advice in enterprise informatization construction steps, implementation model, platform selection and other aspects according to the development pattern of Chinese medical industry.

The contents of medical equipment manufacturing enterprise informatization construction should include daily affairs management system and product related management system, as shown in Figure 3.

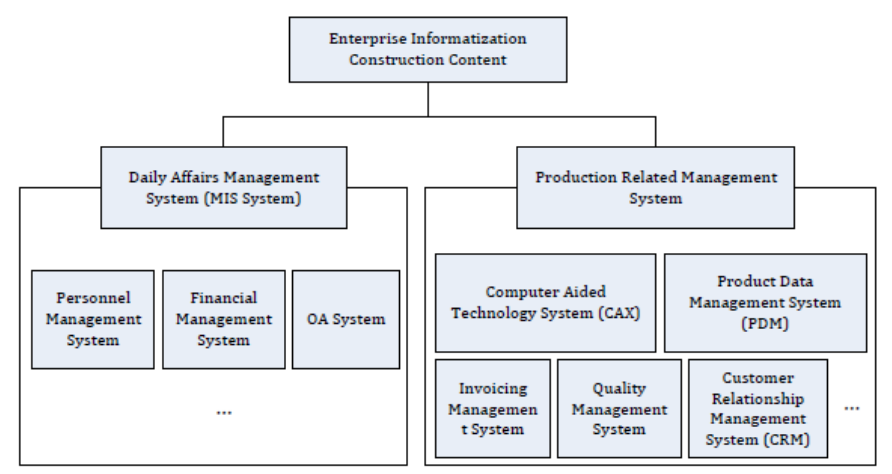

Figure 3. Contents of Medical Equipment Manufacturing Enterprise Informatization Construction

Usually, if the informatization construction of an enterprise is started from blank, we suggest that the enterprise can construct its whole informatization management system as follows, as shown in Figure 4.

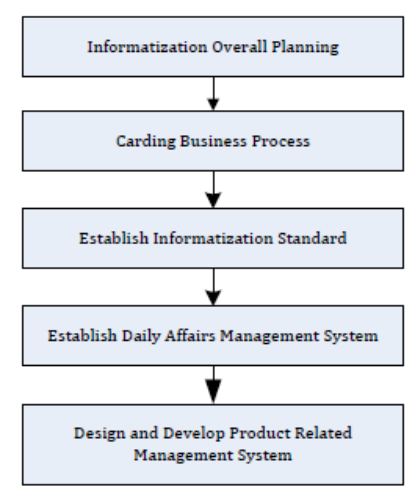

Figure 4. Steps of Medical Equipment Manufacturing Enterprise Informatization Construction

a) Informatization Planning: In the stage of the overall planning of informatization construction, we should solve the problems about the responsibility, the goal and the development direction of the organization from the point of view of whole and macrograph, make it clear that what the purpose and development direction of informatization are, and then set about overall arranging in aspect of data structure, application system, safety system, software and hardware infrastructure construction of the informatization construction.

b) Carding Business Process: In the initial stage of informatization construction, we should make clear the enterprise business scope and process, diagnose the problems existing in business and management process, get known of trend of medical equipment industry and analyze its development status and characteristics, and then mining the main demands and problems in each department of the enterprise, at last, optimize the business process of medical equipment manufacturing enterprise to a certain degree, aiming at solving the existing problems and defects of enterprise. 
c) Establish the Informatization Standard: After finishing the overall planning and optimizing the business process of medical equipment manufacturing enterprise informatization, we should establish the informatization standard and complete the work of data standardization, which is not only the basic guarantee of the information system integration and data sharing, but also one of the most basic and important work to establish the enterprise operation and management platform.

TABLE II. EXAMPLES OF MEDICAL EQUIPMENT INFORMATIZATION DATA STANDARD

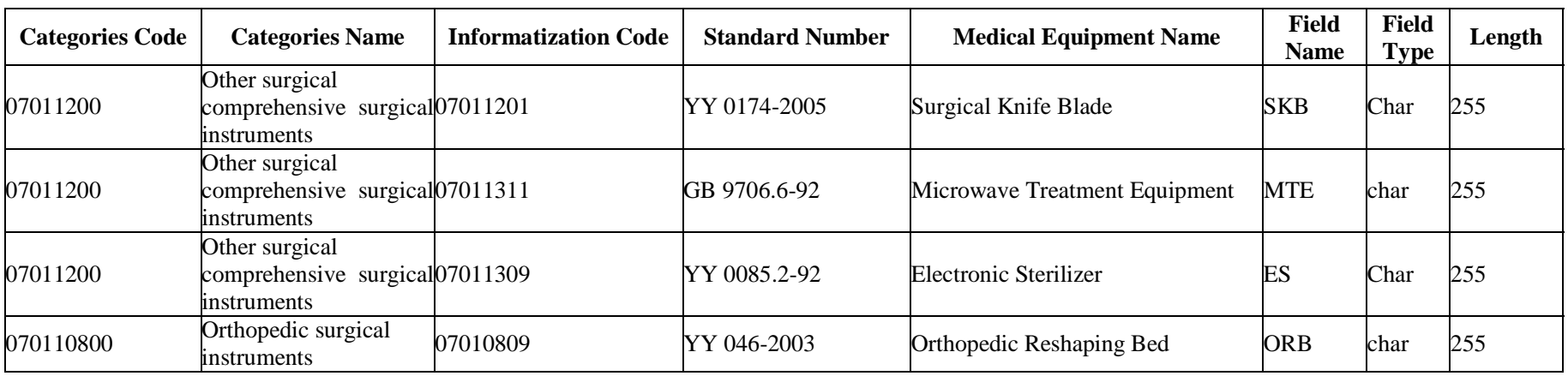

d) Establish Daily Affairs Management System (MIS System): The establishment of MIS system is to solve the fussy and low-efficiency problem between internal departments of enterprise, including personnel management system, financial management system and the establishment of OA system.

e) Design and Develop Product Related Management System: As manufacturing enterprise, the informatization of production and manufacturing management system is one of important contents of enterprise informatization construction. At this stage, we need to design and develop CAX system, PDM system, invoicing management system, quality management system, customer relationship management system and other production related management system.

3) Typical Cases Management of Medical Equipment Manufacturing Enterprise Informatization

Typical cases management module is use to record mature typical cases of enterprise informatization at home and abroad, including their company introduction, informatization infrastructure construction, business informatization system planning, construction and implementation model, platform selection situation, etc. It facilitates users for reference in the informatization construction process, in order to promote the deployment and implementation of domestic medical equipment manufacturing enterprise informatization.

\section{CONCLUSION}

The medical equipment manufacturing enterprise informatization system designed and implemented in this paper provides normative documents, informatization carried standard, main contents of informatization construction, typical cases, informatization construction and implementation model and other management modules. The system can help Chinese medical equipment manufacturing enterprises solve the outstanding problems that they are facing in their process of informatization construction and implementation. Along with the going deep into the actual application of the platform continuously, its function will be improved constantly, and its support strength to medical equipment manufacturing enterprise informatization construction and implementation will also be strengthened.

\section{REFERENCES}

[1] Shaolin Ying, "Domestic and Foreign Literature Review about Enterprise Infromation,” Enterprise Gaining, vol. 21, pp. 188, 2011.

[2] Jie Zhao, The Enterprise Informatization Framework, Tsinghua university press:Jan, 2011.

[3] Ruihong $\mathrm{Mu}$, and Yimei Xiao, "The Analysis and Suggestions on Chinese Medical Equipment Standard Current Situation,” China's drug, vol. 25(7), pp. 657-658, 2011.

[4] Hui Yin, "Idea and Prospect of Medical Equipment Informatization System Management,” Medical Equipment, vol. 1, pp. 102-103, 2012.

[5] Peilin Li, "Enterprise Informatization Management Technology and Case Analysis," Computer Knowledge and Technology, vol. 07(7), pp. 1469-1471, 2011.

[6] Zhiping Hou, and Jinyu Hu, "Information System Evaluation Model Study of Manufacturing Enterprise," International Conference on Information System and Computational Intelligence, 2011. 